\title{
Discovery of the mud shrimp genus Anacalliax de Saint Laurent, 1973 (Decapoda: Callianassidae) in the Brazilian coast
}

\author{
Luciane Augusto de Azevedo Ferreira ${ }^{1,2}$ \& Paulo P.G. Pachelle ${ }^{1,3}$ \\ 1 Universidade de São Paulo (USP), Museu de Zoologia (MZUSP). São Paulo, SP, Brasil. \\ 2 ORCID: http://orcid.org/0000-0003-1683-9962. E-mail: lucianeaaf@gmail.com (corresponding author) \\ ${ }^{3}$ ORCID: http://orcid.org/0000-0003-0093-9352. E-mail: paulopachelle@gmail.com
}

\begin{abstract}
Previously known only from Argentina and Uruguay, Anacalliax argentinensis is herein reported for the first time from Rio de Janeiro, representing the first occurrence of genus Anacalliax in the Brazilian coast and the northernmost record of the species in the Atlantic 0 cean. Morphological variations on the third maxilliped and first pereopods are discussed based in our material.
\end{abstract}

Key-Words. Axiidea; Anacalliax argentinensis; Biodiversity; Ontogeny; Western Atlantic.

\section{INTRODUCTION}

Anacalliax de Saint Laurent, 1973 is currently composed of three Atlantic species. Among them, two are western Atlantic (A. argentinensis (Biffar, 1971) and A. agassizi (Biffar, 1971)) and one eastern Atlantic, A. pixii (Kensley, 1976) (Biffar, 1971; Kensley, 1976; Sakai, 1999, 2005).

The genus is characterized by several morphological features, including carapace with dorsal oval, rostral carina and cardiac prominence; third maxilliped pediform, without exopod, and dactylus more than twice longer than broad; uropodal exopod unilobed, with strong indentation; and first chelipeds slightly unequal (de Saint Laurent, 1973; Sakai, 1999, 2005).

Anacalliax argentinensis so far has been known to occur only from few localities in Argentina and Uruguay (Biffar, 1971; Sakai, 1999, 2005, 2011; Trinchin et al., 2014). The species can be easily separated from $A$. agassizi by the telson with distal margin concave (vs. margin straight in A. agassizi; Biffar, 1971: figs. 2k, 3k), and from $A$. pixii by the antennular peduncle distinctly shorter than the antennal peduncle (vs. about as long as antennal peduncle in A. pixii; Biffar, 1971: fig. 2h; Kensley, 1976: fig. 4A).

Among the material collected during the "Ilha Grande" project conducted in Rio de Janeiro in 1969, a small female of $A$. argentinensis was identified. The specimen, collected off the Angra dos Reis coast at 22 meters depth, represents the first finding of $A$. argentinensis in Brazil and the northernmost record of the species in the Atlantic Ocean.

\section{MATERIAL AND METHODS}

The material is deposited in the carcinological collection of the Museu de Zoologia, Universidade de São Paulo (MZUSP). Drawings were made under a stereomicroscope equipped with a camera lucida. Carapace length ( $\mathrm{cl}$, in $\mathrm{mm}$ ) was measured along the dorsal midline from the tip of the rostrum to the posterior margin of carapace.

Abbreviation included: $M \times p 3$, third maxillipeds; P1-P3, pereopods 1-3; WA, western Atlantic Ocean; EA, eastern Atlantic Ocean.

\section{RESULTS AND DISCUSSION}

Order Decapoda Latreille, 1802

Infraorder Axiidea de Saint Laurent, 1979

Family Callianassidae Dana 1852

\section{Genus Anacalliax de Saint Laurent, 1973}

Anacalliax de Saint Laurent, 1973: 515; Ferrari, 1981: 17; Manning, 1987: 397; Manning \& Felder, 1991: 786, figs. 2-3, 17; Sakai, 1999: 126, 2005: 210, 2011: 343.

\section{Anacalliax argentinensis (Biffar, 1971)}

Fig. 1A-G

Callianassa argentinensis Biffar, 1971: 229, fig. 2. 


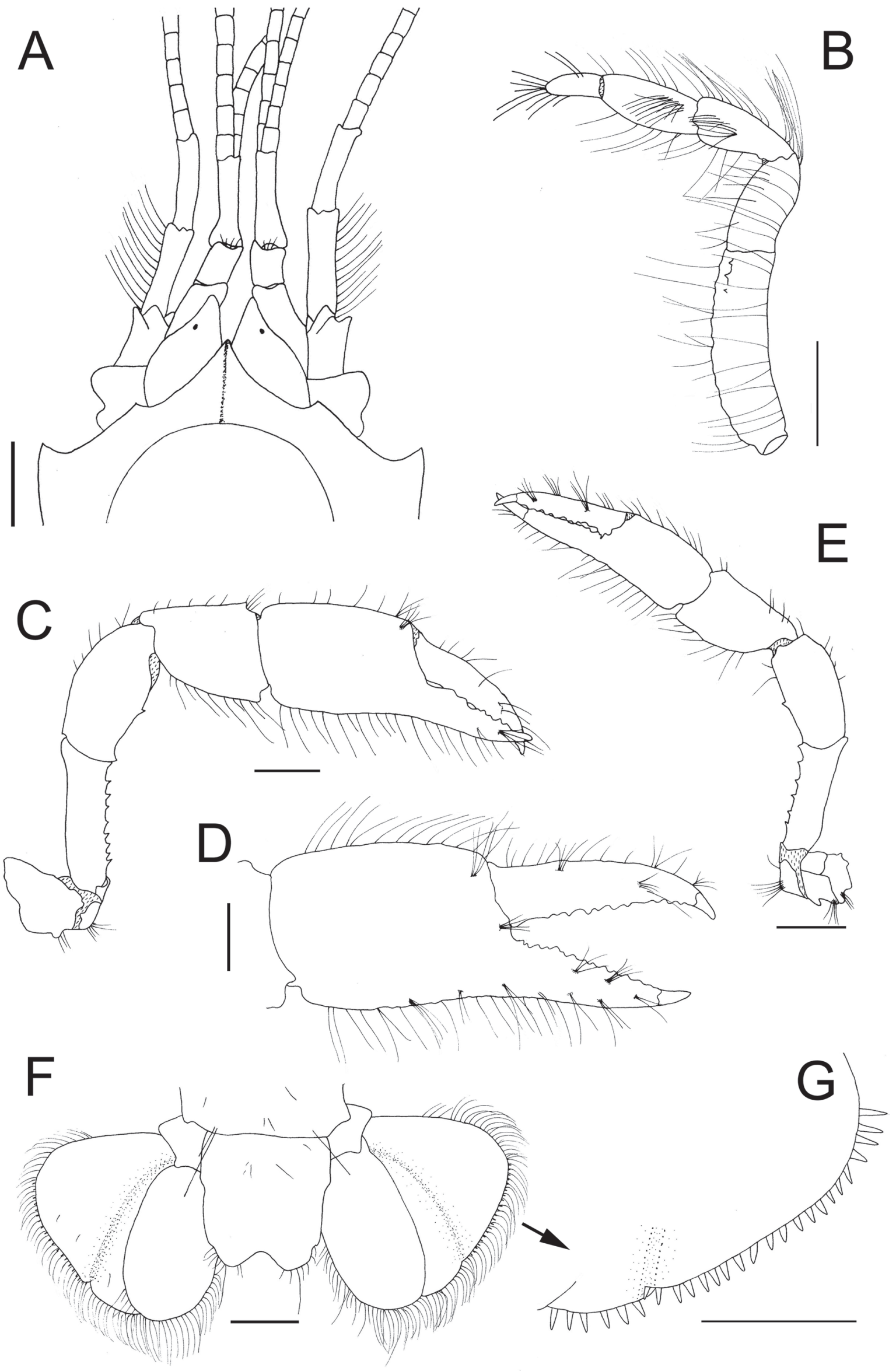

Figure 1. Anacalliax argentinensis (Biffar, 1971), female, cl 4.5 mm (MZUSP 31510). (A) Frontal margin and cephalic appendages, dorsal view. (B) Right Mxp3, mesial view. (C) Right major P1, lateral view. (D) Same, chela, lateral view. (E) Left minor P1, lateral view. (F) Sixth abdominal segment, uropods and telson, dorsal view. (G) Uropodal exopod, detail of the row of spinules on distal margin, plumose setae omitted. Scale bars $=0.5 \mathrm{~mm}$. 
Anacalliax argentinensis (Biffar, 1971); Boschi, 1979: 137, tab. 1; Ferrari, 1981: 17, pl. Ill; Manning, 1987: 397; Manning \& Felder, 1991: 787 (list), figs. 2, 3, 17; Boschi et al., 1992: 40, fig. 34; Sakai, 1999: 127; Tudge et al., 2000: 142 (list); Thatje, 2003: 119 (tab. 1); Sakai, 2005: 211; Sakai, 2011:343, fig. 63A-C; Spivak et al., 2019: 51.

Material examined: female, cl $4.5 \mathrm{~mm}$, MZUSP 31510, Brazil, Rio de Janeiro, Angra dos Reis, station 331, 21.iii.1969, 22 meters depth.

Distribution: Brazil: Rio de Janeiro, Angra dos Reis $\left(23^{\circ} \mathrm{S}\right)$ (present study). Uruguay: Rocha, Cerro Verde $\left(33^{\circ} \mathrm{S}\right)$ (Trinchin et al., 2014). Argentina: Provincia Buenos Aires, Riacho Jabalí, Bahía San Blas and Los Pocitos $\left(40^{\circ} \mathrm{S}\right)$; Provincia Río Negro, Golfo San Matías ( $\left.41^{\circ} \mathrm{S}\right)$; Provicia Santa Cruz, Río Deseado, in front of Isla del Rey $\left(47^{\circ} \mathrm{S}\right)$ (Biffar, 1971; Ferrari, 1981; Sakai, 1999, 2005, 2011).

Remarks: The morphological characters in the female from Brazil agree well with those described by Biffar (1971): (i) Rostral carina present (Fig. 1A); (ii) Mxp3 pediform, with ischium and merus narrow (Fig. 1B); (iii) P1 ischium with row of teeth on ventral margin (Fig. 1C, E); (iv) P1 fingers with cutting edges serrate (Fig. 1D); (v) telson subquadrate, shorter than uropods, with posterior margin medially concave (Fig. 1F).

In the original description, Biffar (1971) states that the Mxp3 ischium is unarmed, i.e., without a crista dentata (cf. Biffar, 1971: fig. 2g). Subsequent studies also depicted the species with a smooth Mxp3 ischium (Ferrari, 1981: pl. III, fig. 7; Manning \& Felder, 1991: fig. 3). However, the present specimen has a short crista dentata of 3 minute teeth on the Mxp3 ischium (Fig. 1B). The chelipeds (P1) also have a different number of teeth on the ventral margin of merus and ischium compared to that reported for the species. In the present specimen, the merus of both major and minor P1 bear only 1 tooth (vs. 2-3 teeth in Biffar, 1971), whilst the ischium has 8 teeth on major and 6 teeth on minor (vs. 5-6 teeth on major and 4-7 teeth on minor in Biffar, 1971). Ferrari (1981) also mentions a specimen with a single tooth on both P1 merus, but with no voucher reference to allow speculation. Nevertheless, the presence of a crista dentata on Mxp3 and the different armature on both $\mathrm{P} 1$ could be juvenile characters, thus changing during the ontogenetic development (note that Biffar (1971)'s types range from 143 to $24 \mathrm{~mm}$ of total length, whilst our specimen is less than $10 \mathrm{~mm}$ long).

Lastly, the presence of spinules on the uropodal exopod is not mentioned in Biffar (1971) nor in Ferrari (1981) (Fig. 1G). However, it is likely that these spinules are present, but were overlooked in both previous studies due to the thick fringe of plumose setae on distal margin (Fig. 1F; see a similar case in Pachelle et al. (2017: 348) for Neocallichirus maryae Karasawa, 2004).

\section{ACKNOWLEDGMENTS}

We are grateful to Dr Marcos Tavares (MZUSP) for providing working space and access to the collection under his care. We also thank Dr Fabrizio Scarabino (MUNHN) for providing valuable comments and criticism that improved the originally submitted manuscript.

\section{REFERENCES}

Biffar, T.A. 1971. New species of Callianassa (Decapoda, Thalassinidea) from the western Atlantic. Crustaceana, 21(3): 225-236.

Boschi, E.E. 1979. Geographic distribution of Argentinian marine decapod crustaceans. Bulletin of the Biological Society of Washington, 3: 134-143.

Boschi, E.E.; Fischbach, C.E. \& Iorio, M.I. 1992. Catálogo ilustrado de los crustáceos estomatópodos y decápodos marinos de Argentina. Frente Maritimo, 10(A): 7-94.

de Saint Laurent, M. 1973. Sur la systematique et la phylogenie des Thalassinidea: definition des families des Callianassidae et des Upogebiidae et diagnose de cinq genres nouveaux (Crustacea Decapoda). Comptes rendus de l'Académie des Sciences, (D), Paris, 277: 513-516.

Ferrari, F. 1981. Aportes para el conocimiento de la Familia Callianassidae (Decapoda, Macrura) en el oceano Atlantico Sudoccidental. Physis, Buenos Aires, 39(97): 11-21.

Karasawa, H. 2004. Neocallichirus maryae, a replacement name for Neocallichirus rathbunae (Schmitt, 1935) (Crustacea: Decapoda: Thalassinidea). Paleontological Research, 8: 87.

Kensley, B. 1976. Records of mud-prawns (genus Callianassa) from South Africa and Mauritius (Crustacea, Decapoda, Thalassinidea). Annals of the South African Museum, 69(3): 47-58.

Manning, R.B. 1987. Notes on western Atlantic Callianassidae (Crustacea: Decapoda: Thalassinidea). Proceedings of the Biological Society of Washington, 100(2): 386-401.

Manning, R.B. \& Felder, D.L. 1991. Revision of the American Callianassidae (Crustacea: Decapoda: Thalassinidea). Proceedings of the Biological Society of Washington, 104: 764-792.

Pachelle, P.P.G., Anker, A. \& Bezerra, L.E.A. 2017. Re-identification of the material of Neocallichirus maryae Karasawa, 2004 from Ceará, northeastern Brazil, with the first record of $N$. cacahuate Felder \& Manning, 1995 in the southwestern Atlantic. Zootaxa, 4276: 346-356.

Sakai, K. 1999. Synopsis of the family Callianassidae, with keys to subfamilies, genera and species, and the description of new taxa (Crustacea: Decapoda: Thalassinidea). Zoologische Verhandelingen, Leiden, 326: 1-152.

Sakai, K. 2005. Callianassoidea of the World (Decapoda: Thalassinidea). Crustaceana Monographs, 4: 1-285.

Sakai, K. 2011. Axioidea of the World and a reconsideration of the Callianassoidea (Decapoda, Thalassinidea, Callianassida). Crustaceana Monographs, 14: 1-616.

Spivak, E.D.; Farías, N.E.; Ocampo, E.H.; Lovrich, G.A.; Luppi, T.A. 2019. Annotated catalogue and bibliography of marine and estuarine shrimps, lobsters, crabs and their allies (Crustacea: Decapoda) of Argentina and Uruguay (Southwestern Atlantic Ocean). Frente Marítimo, 26: 1-164.

Thatje, S. 2003. Review of the Thalassinidea (Crustacea: Decapoda) from Chile and Argentina. Anales Instituto Patagonia, 31: 115-122.

Trinchin, R.; Leoni, V.; Rabellino, J.; Serra, W.S.; Carranza, A.; Scarabino, F. \& Segura, A. 2014. Diversidad de crustáceos decápodos del Área Marina Protegida Cerro Verde y su zona costera aledaña. In: Congreso Uruguayo de Zoología "Prof. Dr. Raúl Vaz-Ferreira", 3º Resúmenes. Montevideo, Sociedad Zoologica des Uruguay. p. 283.

Tudge, C.C.; Poore, G.C.B. \& Lemaitre, R. 2000. Preliminary phylogenetic analysis of generic relationships within the Callianassidae and Ctenochelidae (Decapoda: Thalassinidea: Callianassoidea). Journal of Crustacean Biology, 20(special number 2): 129-149. 